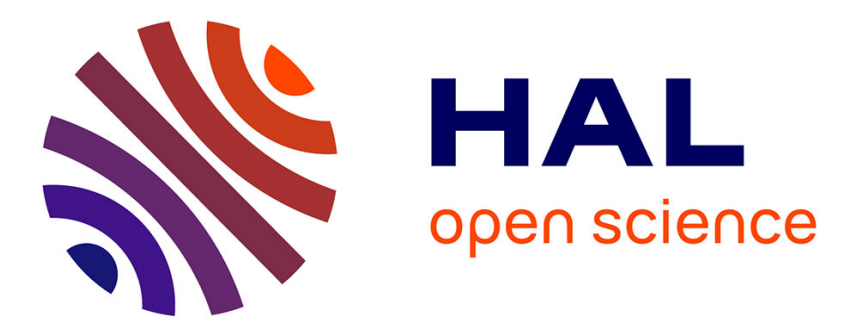

\title{
Free-air CO2 enrichment modifies maize quality only under drought stress
}

Martin Erbs, Remy Manderscheid, Liane Hüther, Anke Schenderlein, Herbert Wieser, Sven Dänicke, Hans-Joachim Weigel

\section{> To cite this version:}

Martin Erbs, Remy Manderscheid, Liane Hüther, Anke Schenderlein, Herbert Wieser, et al.. Freeair CO2 enrichment modifies maize quality only under drought stress. Agronomy for Sustainable Development, 2015, 35 (1), pp.203-212. 10.1007/s13593-014-0226-5 . hal-01284251

\section{HAL Id: hal-01284251 \\ https://hal.science/hal-01284251}

Submitted on 7 Mar 2016

HAL is a multi-disciplinary open access archive for the deposit and dissemination of scientific research documents, whether they are published or not. The documents may come from teaching and research institutions in France or abroad, or from public or private research centers.
L'archive ouverte pluridisciplinaire HAL, est destinée au dépôt et à la diffusion de documents scientifiques de niveau recherche, publiés ou non, émanant des établissements d'enseignement et de recherche français ou étrangers, des laboratoires publics ou privés. 


\title{
Free-air $\mathrm{CO}_{2}$ enrichment modifies maize quality only under drought stress
}

\author{
Martin Erbs • Remy Manderscheid • Liane Hüther • \\ Anke Schenderlein • Herbert Wieser • Sven Dänicke • \\ Hans-Joachim Weigel
}

Accepted: 24 March 2014 / Published online: 25 April 2014

(C) INRA and Springer-Verlag France 2014

\begin{abstract}
Climate scenarios show that atmospheric $\mathrm{CO}_{2}$ concentrations will continue to increase. As a consequence, more frequent and severe drought periods are expected. Drought will thus modify plant growth. Although maize is a major crop globally, little information is available on how atmospheric and climatic changes will change maize quality. Here, in a field experiment, maize was grown in 2007 and 2008 under ambient (380 ppm) and elevated $\mathrm{CO}_{2}(550 \mathrm{ppm})$ using free-air $\mathrm{CO}_{2}$ enrichment. In 2007, maize was grown under wellwatered conditions only. In 2008, we applied a drought stress treatment in which the plants received only half the amount of water of the well-watered treatment. We measured the concentrations of minerals and quality-related traits in aboveground biomass and kernels at the end of each growing season. Results show first the absence of effect of elevated $\mathrm{CO}_{2}$ under well-watered conditions. By contrast, drought stress modified several traits and interactions under elevated $\mathrm{CO}_{2}$. These results support the hypothesis that the $\mathrm{C} 4$ plant maize does not react to an increase in atmospheric $\mathrm{CO}_{2}$ as long as no drought stress is prominent. This finding contrasts with the impact of elevated $\mathrm{CO}_{2}$ on $\mathrm{C} 3$ plants. Several drought stress effects found in our study will have important implications for food and feed use. However, the effects of drought
\end{abstract}

\footnotetext{
M. Erbs $(\triangle) \cdot$ R. Manderscheid $\cdot$ H.-J. Weigel

Thünen Institute of Biodiversity, Federal Research Institute for

Agriculture, Fisheries and Forestry, Bundesallee 50,

38116 Braunschweig, Germany

e-mail: martin.erbs@ti.bund.de

L. Hüther · A. Schenderlein · S. Dänicke

Institute of Animal Nutrition, Friedrich Loeffler-Institut, Federal

Research Institute for Animal Health, Bundesallee 50,

38116 Braunschweig, Germany

H. Wieser

German Research Centre for Food Chemistry, Lise-Meitner-Straße 34, 85354 Freising, Germany
}

stress on the traits were less pronounced under elevated $\mathrm{CO}_{2}$ than under ambient $\mathrm{CO}_{2}$ level. Hence, an elevated $\mathrm{CO}_{2}$ concentration mitigates the drought stress impacts on elemental composition and quality traits of maize.

Keywords Carbon dioxide $\cdot$ Climate change $\cdot$ FACE $\cdot$ Fiber fractions $\cdot$ Food and feed $\cdot$ Free-air $\mathrm{CO}_{2}$ enrichment . Microelements $\cdot$ Minerals $\cdot$ Protein fractions $\cdot$ Rain shelter . Stoichiometry $\cdot$ Water availability $\cdot$ Water deficit $\cdot$ Zeamaize

\section{Introduction}

With regard to food supply, the global demand for maize is projected to exceed that for wheat and rice within the next decades (Pingali 2009), and already, today, maize is the second most important crop globally (FAO 2011). In spite of this importance of maize, only a few studies have been carried out which have addressed the combined effects of more than a single anticipated climate change factor on this relevant crop (Leakey et al. 2006; Manderscheid et al. 2014). A main driver of global climate change is the increase in atmospheric carbon dioxide $\left(\mathrm{CO}_{2}\right)$ concentration, which is expected to exceed $550 \mu \mathrm{mol} \mathrm{mol}^{-1}$ by the middle of the twenty-first century (Meehl et al. 2007). Crops of the $\mathrm{C}_{3}$ type are known to show an increased photosynthesis as well as enhanced growth and yield under elevated $\mathrm{CO}_{2}$ (Kimball et al. 2002; Long et al. 2006). In contrast, photosynthesis of $\mathrm{C}_{4}$ plants like maize is not influenced directly by rising $\mathrm{CO}_{2}$ because current $\mathrm{CO}_{2}$ concentrations are not rate-limiting to their photosynthesis. However, stomatal conductance of both $\mathrm{C}_{3}$ and $\mathrm{C}_{4}$ plants is reduced by $\mathrm{CO}_{2}$ enrichment, resulting in a reduced transpiration and an improved water status (Ghannoum 2009). A few experimental results available indicate that, for $\mathrm{C}_{4}$ crops, elevated $\mathrm{CO}_{2}$ impacts might also result in yield increases. The underlying reason could be the reduced water 
consumption that mitigates drought stress by conserving soil moisture (Ghannoum et al. 2000; Leakey et al. 2006; Markelz et al. 2011; Manderscheid et al. 2014).

Along with an increased biomass production, $\mathrm{C}_{3}$ plants grown under $\mathrm{CO}_{2}$ enrichment frequently show changes of their chemical composition, e.g. diminished concentrations of minerals and other quality-related components (Loladze 2002; Wang and Frei 2011). Among the various mechanisms that are discussed as putative causes for these changes are (1) a dilution effect due to the surplus of assimilated carbon compounds and (2) a reduced plant uptake of elements from the soil due to reduced transpirational water flow through the plant (Taub and Wang 2008; McGrath and Lobell 2013). As the second mechanism may also be relevant for $\mathrm{C}_{4}$ plants, the concentrations of minerals in these plants should also be affected by elevated $\mathrm{CO}_{2}$ (Lindroth and Dearing 2005; Ghannoum et al. 2006). A meta-analysis by McGrath and Lobell (2013) revealed that the decrease of nutrients acquired mostly by mass flow like potassium, calcium and magnesium is more pronounced under elevated $\mathrm{CO}_{2}$. Overall, $\mathrm{CO}_{2}$-induced changes in elemental composition and quality characteristics could potentially have negative consequences for the nutritional quality of food and feed and for the element turnover of ecosystems. Both elevated $\mathrm{CO}_{2}$ and drought stress affect plant-water relations. Hence, these two climate change factors interact in their impact on the chemical composition of plants. However, for $\mathrm{C}_{4}$ crops and particularly for maize, there is currently no information available from field studies that have addressed this important topic. In their review, McGrath and Lobell (2013) pointed out that the relationship between plant transpiration and nutrient concentrations should be examined under realistic environmental conditions in order to gain a deeper understanding of the underlying processes.

Impacts of elevated $\mathrm{CO}_{2}$ on the quality of $\mathrm{C}_{3}$ grain crops have been examined in several field studies using free-air $\mathrm{CO}_{2}$ enrichment (FACE) technique (Long et al. 2006; Högy and Fangmeier 2008). In contrast, elevated $\mathrm{CO}_{2}$ effects on elemental composition and quality characteristics of $\mathrm{C}_{4}$ plants like maize have not been evaluated under such experimental conditions. Findings from the small number of field studies on drought stress effects on maize are contradictory. For example, Kruse et al. (2008) identified temperature and radiation as main drivers for quality changes in maize, while Crasta et al. (1997) found plant available soil water content to be the most relevant factor for maize forage quality. Currently, there is no information from field studies available on the interactions of elevated $\mathrm{CO}_{2}$ and drought on quality characteristics of $\mathrm{C}_{4}$ crops like maize, although the necessity for such experiments has clearly been pointed out by several authors (Leakey et al. 2006; Ghannoum et al. 2006; Ainsworth et al. 2008; Wang and Frei 2011).

Previous results which originated from the same experiment (Manderscheid et al. 2014) have shown that maize yield did not respond to elevated $\mathrm{CO}_{2}$ under ample water supply while, under drought stress, there was significant yield stimulation due to elevated $\mathrm{CO}_{2}$. In this study, a main effect of elevated $\mathrm{CO}_{2}$ was an increase in water-use efficiency accompanied by a reduction in soil water depletion which caused a delay in the incidence of drought stress, leading to better performance of maize under drought. As these results point to reduced transpirational water flow, it was of interested to investigate whether this may result in an altered elemental composition of maize aboveground biomass and kernel tissue. In the present study, the impacts of free-air $\mathrm{CO}_{2}$ enrichment and low water availability on elemental composition and quality traits of field-grown maize are presented. We tested the following hypotheses: (1) an increase in atmospheric $\mathrm{CO}_{2}$ concentration reduces the transpiration of maize and thus the amount of minerals transported by the transpiration flux. In our study, it was examined whether the concentrations of minerals in aboveground biomass and kernels of maize are generally decreased under elevated $\mathrm{CO}_{2}$. (2) Elevated $\mathrm{CO}_{2}$ reduces plant transpiration which leads to a slower depletion of soil water by plants which in turn leads to a later incidence of drought stress under $\mathrm{CO}_{2}$ enrichment. In our study, we examined if an increase in $\mathrm{CO}_{2}$ will mitigate the drought stress-induced effects on the concentrations of minerals and quality traits. To our knowledge, this is the first report on impacts of combined elevated $\mathrm{CO}_{2}$ and controlled drought stress on elemental composition and quality traits in maize grown under real agronomic conditions.

\section{Material and methods}

\subsection{Field conditions and experimental treatments}

The experiment was carried out on a 7-ha field site of the experimental station of the Friedrich Loeffler-Institut, Braunschweig, South-East Lower Saxony, Germany $\left(52^{\circ} 18^{\prime} \mathrm{N}, 10^{\circ} 26^{\prime} \mathrm{E}, 79 \mathrm{~m}\right.$ asl). The soil at the experimental area is a luvisol of a loamy sand texture in the plough horizon with a $\mathrm{pH}$ of 6.5 , a mean organic matter content of $1.4 \%$ and a comparatively shallow rooting zone $(0-0.6 \mathrm{~m})$. The subsoil consists of a mixture of gravel and sand. The drained upper and lower limits ( 0.01 and $1.5 \mathrm{MPa}$ soil water tension) of plant available volumetric soil water content within the $0.6 \mathrm{~m}$ soil profile are about $23 \%$ and $5 \%$, respectively. The plant available water capacity within the rooting zone is about $100 \mathrm{~mm}$. A FACE system engineered by Brookhaven National Laboratory was operated that consisted of three circular plots of $20 \mathrm{~m}$ in diameter with an enhanced seasonal average $\mathrm{CO}_{2}$ concentration of $549 \mu \mathrm{mol} \mathrm{mol}^{-1}$ in both years. Another three circular plots of the same size served as controls with seasonal average ambient $\mathrm{CO}_{2}$ levels of 382 and $385 \mu \mathrm{mol} \mathrm{mol}^{-1}$ in the 2 years, respectively. In 2008 , all of 
the six circular main plots were split into two semicircles to establish a well-watered and a drought stress subplot treatment. The drought stress subplots were equipped with tent frames of a size of $12 \times 20 \mathrm{~m}$ each (Fig. 1) which were covered with transparent PVC tarpaulins during periods of forecasted rainfall of $>10 \mathrm{~mm} \mathrm{day}^{-1}$ (Erbs et al. 2012). In the wellwatered subplots, soil water content in the $0-0.6 \mathrm{~m}$ profile was kept above $50 \%$ of maximum by drip irrigation. In the drought stress treatment, soil water content in the $0-0.6 \mathrm{~m}$ profile was reduced to about $20 \%$ of the well-watered subplot content from the middle of the 2008 growing season on (Manderscheid et al. 2014).

\subsection{Crop management and environmental conditions}

Agricultural management of the field site and the experimental plots was carried out according to local farm practice. Maize (Zea mays L., cv. 'Romario') was sown with a row distance of $0.75 \mathrm{~m}$ and a seeding density of 10 plants $\mathrm{m}^{-2}$. Weed control was done by application of herbicides in May and manual weeding in the experimental plots. Mineral nutrients were added according to local fertilising practice based on soil analysis in early springtime. The following amounts of fertilisers were applied per hectare in 2007: $171 \mathrm{~kg}$ nitrogen (ammonium and urea), $92 \mathrm{~kg}$ phosphorous $\left(\mathrm{P}_{2} \mathrm{O}_{5}\right), 200 \mathrm{~kg}$ potassium $\left(\mathrm{K}_{2} \mathrm{O}\right)$ and $36 \mathrm{~kg}$ sulfur. In 2008, the following amounts of fertilisers were applied per hectare: $198 \mathrm{~kg}$ nitrogen (ammonium and urea), $92 \mathrm{~kg}$ phosphorous $\left(\mathrm{P}_{2} \mathrm{O}_{5}\right), 25 \mathrm{~kg}$ magnesium $(\mathrm{MgO})$ and $20 \mathrm{~kg}$ sulfur. The anthesis stage was reached at 18th and 25th of July in 2007 and 2008, respectively, and did not differ between the treatments. For the years 1971-2000, mean air temperature was $8.8^{\circ} \mathrm{C}$; mean air temperature of July (warmest month) was $17.0^{\circ} \mathrm{C}$; sum of precipitation amounted to $618 \mathrm{~mm}$ (half of it deposited between

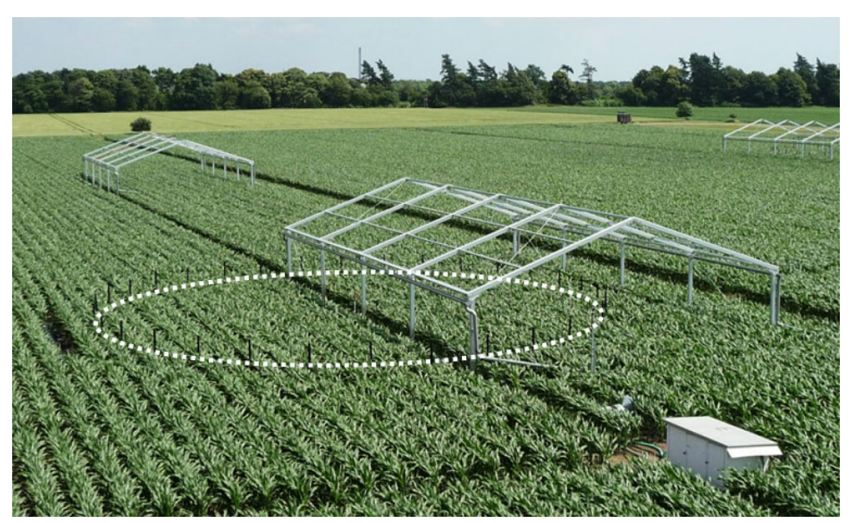

Fig. 1 The experimental maize field showing the plots with the frames of the rain shelter tents without tarpaulins installed. At the plot in the front the free-air $\mathrm{CO}_{2}$ enrichment (FACE) area is denoted by the white dashed circle. The surrounding black tubes are vertical vent pipes for $\mathrm{CO}_{2}$ release. At each of the circular plots, one half is covered by the tent (drought stress treatment), and the other half is equipped with drip irrigation (well-watered treatment)
May and September), and 1,514 h of sunshine were recorded. The two growing seasons largely differed from each other. While the later 2007 growing season was very rainy, the 2008 growing season was rather dry, with sums of precipitation between June and September of 386 and 209 mm, respectively. A more detailed description of the climatic conditions, soil moisture measurements and respective data is given in Erbs et al. (2012) and Manderscheid et al. (2014).

\subsection{Plant sampling}

All plant samples for the analyses were taken at final harvest in both of the growing seasons. For the final harvests, the plants of an area of $2 \mathrm{~m}^{2}$ in all plots of the treatments were cropped resulting in 12 samples $\left(2 \times 3\right.$ plots for both $\mathrm{CO}_{2}$ treatments with each of them divided into two water treatments). From each sample, ten representative plants were chaffed on the whole and used for the evaluation of traits in aboveground biomass. The other plants of a sample were separated into leaves, stems and cobs. Kernels from these cobs were used in the present study.

\subsection{Measurements of elemental composition}

Elemental composition was determined directly from ground sample material of aboveground biomass and kernels for nitrogen and sulphur using an element analyser (TruSpec CNS, Leco). For the analyses of the mineral concentrations of phosphorus, potassium, calcium, magnesium, iron and zinc, sample material was prepared with incineration followed by disintegration with nitric acid. Except for phosphorus, all other elements were analysed by atomic absorption spectrometry (AA-200, Varian) referring to a poplar leaf standard (NCS DC73350, Breitländer) at the following wavelengths: potassium $766.5 \mathrm{~nm}$, calcium $422.7 \mathrm{~nm}$, magnesium $285.2 \mathrm{~nm}$, iron $248.3 \mathrm{~nm}$ and zinc $213.9 \mathrm{~nm}$. Sample phosphorus concentration was assessed photometrically as acidic ammonium molybdate complex at $880 \mathrm{~nm}$ (Segmented Flow Analyzer, Skalar Analytic).

\subsection{Measurements of quality characteristics}

The crude nutrient contents were analysed according to the methods of the Association of German Agricultural Analytic and Research Institutes (VDLUFA 2006). Crude fiber was investigated according to method number 6.1.1 of VDLUFA (2006), and acid detergent fiber analysis was carried out by using method number 6.5.2. Neutral detergent fiber and lignin were determined as described by van Soest et al. (1991). All fiber fractions were expressed without residual ash. Fat content was determined by the Soxhlet extraction method after acid digestion (method number 5.1.1). Sucrose was analysed according to the method of Luff-Schoorl (method number 
7.1.1) and starch by using the polarimetric method (method number 7.2.1). Protein fractions were analysed only for the 2008 plant material. The extraction was carried out according to a modified Osborne fractionation developed for wheat flour (Wieser et al. 1998). Separation and quantitation of fractions were performed by reversed-phase high-performance liquid chromatography using a Beckman instrument (solvent module 126). Filtered extracts were injected into a Nucleosil column (Macherey-Nagel, Dueren), and a linear gradient was applied for protein elution. The quantitation of glutelins and prolamins was based on UV absorbance at $210 \mathrm{~nm}$, which is highly correlated with the amount of eluted proteins (Wieser et al. 1998).

\subsection{Statistical analysis}

Data were analysed with the R statistical software (R 2.14.0, The R Foundation for Statistical Computing). Shapiro-Wilks tests for normal distribution were applied to all data, and in cases of $p>0.10$, data were log-transformed for the analyses of variance. Analyses of variance were carried out including only data of the well-watered treatments of both growing seasons with the factors $\mathrm{CO}_{2}$ and year. Additionally, for the 2008 data, split-plot analyses of variance were calculated based on the averages of the semicircles with $\mathrm{CO}_{2}$ as main factor and water supply as split-plot factor.

\section{Results and discussion}

As a result of previous research of the present experiment, Manderscheid et al. (2014) have shown that maize yield did not respond to elevated $\mathrm{CO}_{2}$ under ample water supply while, under drought stress conditions, there was significant yield stimulation due to $\mathrm{CO}_{2}$ enrichment. A main effect of elevated $\mathrm{CO}_{2}$ in the study of Manderscheid et al. (2014) was an enhanced water use efficiency of the maize canopies accompanied by a reduction in soil water depletion, which resulted in a better growth performance. Thus, clear interactions between the $\mathrm{CO}_{2}$ and water treatment were found. In the present study, no significant impacts of elevated $\mathrm{CO}_{2}$ were observed in the data of the well-watered treatment from both growing seasons. However, in several traits, impacts of the growing season (factor year) became obvious, but no interactions with the $\mathrm{CO}_{2}$ treatment were found. It is assumed that the underlying reason was the difference in precipitation and hence water supply between the two growing seasons (Erbs et al. 2012; Manderscheid et al. 2014). Effects of $\mathrm{CO}_{2}$ were only significant in the split-plot analyses of the 2008 data in which interactions with the drought stress treatment were also observed (Table 1). In the subsequent discussion, all treatmentinduced significant percentage changes in the traits refer to the respective results of the ambient $\mathrm{CO}_{2}$, well-watered treatment used as reference.

\subsection{Elemental composition of maize aboveground biomass}

For maize, aboveground biomass of the well-watered treatment effects of the growing seasons was found for nitrogen, phosphorous, calcium, iron and zinc (Table 1). In 2008, the nitrogen concentration was increased by $\mathrm{CO}_{2}$ enrichment by $2 \%$ (Table 2, Fig. 2). Drought increased the nitrogen concentration by $25 \%$ and $4 \%$ under ambient and elevated $\mathrm{CO}_{2}$, respectively. These higher nitrogen levels will be advantageous for the nutritive value of maize (Johnson et al. 1999). Drought-induced increases in nitrogen concentrations have also been found in several studies on $C_{3}$ crops (Wang and Frei 2011; McGrath and Lobell 2013). Biomass calcium concentration was reduced under drought by $24 \%$ in ambient and $20 \%$ in elevated $\mathrm{CO}_{2}$. The magnesium concentration was increased under drought stress by $15 \%$ and $3 \%$ under ambient and elevated $\mathrm{CO}_{2}$, respectively. Magnesium is mostly transported passively by transpirational water flow (Mota Oliveira et al. 2010), and thus, the magnesium concentration should be reduced under drought. This is in contrast to our results on both aboveground biomass and kernels. In their review, McGrath and Lobell (2013) summarised that concentrations of nutrients acquired mostly by mass flow like potassium, calcium and magnesium decrease under elevated $\mathrm{CO}_{2}$. This is only confirmed for calcium by our results. Rastija et al. (2010) found drought stress to increase zinc concentration in maize, and a positive correlation was found between zinc and phosphorous concentration. However, our data on maize biomass do not support these findings, whereas in kernels a drought-induced increase in zinc concentrations was observed. Significant interactions between the $\mathrm{CO}_{2}$ and water treatment were found for concentrations of nitrogen in which elevated $\mathrm{CO}_{2}$ attenuated the respective drought stress impacts.

\subsection{Elemental composition of maize kernels}

The mineral concentrations of maize kernels (Table 2) were in the same order of magnitude as found in other studies (Nuss and Tanumihardjo 2010). The data of the well-watered treatment from both growing seasons did not reveal a similar influence of the factor year as was observed in elemental composition of aboveground biomass, and only results on nitrogen and calcium were affected. In 2008 (Tables 1 and 2, Fig. 2), the nitrogen concentration was decreased due to $\mathrm{CO}_{2}$ enrichment by $1 \%$, while drought-induced increases of $38 \%$ and $8 \%$ were observed under ambient and elevated $\mathrm{CO}_{2}$, respectively. In terms of nutritive value, the drought stressinduced increase in nitrogen concentration would be advantageous, which is partly diluted by elevated $\mathrm{CO}_{2}$. Drought reduced the potassium concentration by $8 \%$ and $13 \%$ in 
Table 1 Results of the two statistical evaluations of the elemental composition (Minerals) and quality characteristics (Quality) of maize aboveground biomass and kernels

\begin{tabular}{|c|c|c|c|c|c|c|c|c|c|c|c|c|c|c|c|c|c|}
\hline \multicolumn{2}{|c|}{ Minerals } & \multicolumn{8}{|c|}{ Aboveground biomass } & \multicolumn{8}{|l|}{ Kernels } \\
\hline & $p$ level & $\mathrm{N}$ & $\mathrm{P}$ & $\mathrm{K}$ & $\mathrm{Ca}$ & $\mathrm{Mg}$ & $\mathrm{S}$ & $\mathrm{Fe}$ & $\mathrm{Zn}$ & $\mathrm{N}$ & $\mathrm{P}$ & K & $\mathrm{Ca}$ & $\mathrm{Mg}$ & S & $\mathrm{Fe}$ & $\mathrm{Zn}$ \\
\hline \multirow[t]{3}{*}{ WW } & $\mathrm{CO}_{2}$ & 0.641 & 0.941 & 0.164 & 0.842 & 0.243 & 0.485 & 0.345 & 0.295 & 0.576 & 0.645 & 0.141 & 0.751 & 0.212 & 0.054 & 0.622 & 0.798 \\
\hline & Year & $>0.001$ & $>0.001$ & 0.955 & 0.041 & 0.342 & 0.276 & 0.038 & 0.004 & $>0.001$ & 0.117 & 0.830 & 0.020 & 0.206 & 0.108 & 0.486 & 0.699 \\
\hline & $\mathrm{CO}_{2} \times$ Year & 0.366 & 0.835 & 0.369 & 0.359 & 0.787 & 0.996 & 0.896 & 0.971 & 0.312 & 0.279 & 0.671 & 0.165 & 0.270 & 0.256 & 0.304 & 0.733 \\
\hline \multirow[t]{3}{*}{2008} & $\mathrm{CO}_{2}$ & 0.013 & 0.435 & 0.117 & 0.481 & 0.053 & 0.778 & 0.510 & 0.732 & 0.012 & 0.102 & 0.479 & 0.937 & 0.049 & 0.300 & 0.616 & 0.181 \\
\hline & $\mathrm{H}_{2} \mathrm{O}$ & 0.007 & 0.880 & 0.180 & 0.009 & 0.031 & 0.201 & 0.961 & 0.710 & 0.010 & 0.205 & 0.001 & 0.068 & 0.002 & 0.127 & 0.235 & 0.004 \\
\hline & $\mathrm{CO}_{2} \times \mathrm{H}_{2} \mathrm{O}$ & 0.011 & 0.064 & 0.926 & 0.435 & 0.170 & 0.251 & 0.723 & 0.454 & 0.046 & 0.156 & 0.036 & 0.164 & 0.017 & 0.110 & 0.399 & 0.01 \\
\hline
\end{tabular}

Quality

\begin{tabular}{lllllllllllll}
\multicolumn{1}{l}{} & $p$ level & Fat & $\mathrm{CF}$ & Lignin & $\mathrm{ADF}$ & $\mathrm{NDF}$ & Starch & Glut & Prol & Fat & Starch & Sucrose \\
WW & $\mathrm{CO}_{2}$ & 0.361 & 0.666 & 0.065 & 0.533 & 0.959 & 0.658 & 0.753 & 0.760 & 0.289 & 0.172 & 0.058 \\
& Year & 0.093 & 0.090 & 0.178 & 0.366 & $>\mathbf{0 . 0 0 1}$ & $\mathbf{0 . 0 0 8}$ & n.a. & n.a. & $\mathbf{0 . 0 1 8}$ & $\mathbf{0 . 0 1 8}$ & $>\mathbf{0 . 0 0 1}$ \\
& $\mathrm{CO}_{2} \times$ year & 0.954 & 0.829 & 0.729 & 0.833 & 0.848 & 0.644 & n.a. & n.a. & 0.442 & 0.668 & 0.589 \\
2008 & $\mathrm{CO}_{2}$ & 0.123 & 0.633 & 0.421 & 0.316 & 0.298 & 0.089 & $\mathbf{0 . 0 0 4}$ & $\mathbf{0 . 0 1 0}$ & 0.961 & $\mathbf{0 . 0 1 3}$ & 0.142 \\
$\mathrm{H}_{2} \mathrm{O}$ & 0.148 & $\mathbf{0 . 0 4 0}$ & 0.092 & $\mathbf{0 . 0 1 0}$ & $\mathbf{0 . 0 0 4}$ & $\mathbf{0 . 0 3 5}$ & $\mathbf{0 . 0 0 6}$ & $\mathbf{0 . 0 1 1}$ & 0.053 & 0.082 & 0.172 \\
$\mathrm{CO}_{2} \times \mathrm{H}_{2} \mathrm{O}$ & 0.306 & 0.325 & 0.095 & 0.086 & 0.099 & 0.069 & 0.055 & 0.108 & 0.534 & 0.104 & 0.430 \\
\hline
\end{tabular}

$W W$ refers to the results of analyses of variance including only the data of plants grown under well-watered conditions and two $\mathrm{CO}_{2}$ treatments (ambient and elevated $\mathrm{CO}_{2}$ ) from both growing seasons (2007 and 2008), 2008 refers to the results of split-plot analyses of variance including the data of the plants from the 2008 growing season grown under two $\mathrm{CO}_{2}$ treatments (ambient and elevated $\mathrm{CO}_{2}$ ) and two water treatments (well-watered and drought stressed-factor $\mathrm{H}_{2} \mathrm{O}$ ), $N$ nitrogen, $P$ phosphorous, $K$ potassium, $C a$ calcium, $M g$ magnesium, $S$ sulphur, $F e$ iron, $Z n$ zinc, $C F$ crude fiber, $A D F$ acid detergent fiber, NDF neutral detergent fiber, Glut glutelin, Prol prolamin, n.a. not assessed

Significant results $(p<0.05)$ are shown in bold

ambient and elevated $\mathrm{CO}_{2}$, respectively. $\mathrm{CO}_{2}$ enrichment reduced the magnesium concentration by $1 \%$, while drought stress resulted in increases of $23 \%$ under ambient and $6 \%$ under elevated $\mathrm{CO}_{2}$. For zinc, drought stress caused an increase in the concentrations of $29 \%$ and $3 \%$ in ambient and elevated $\mathrm{CO}_{2}$, respectively. Oktem (2008) showed that maize kernel concentrations of iron and zinc were reduced under low water supply in the field, while protein concentration was increased. In our study, nitrogen concentration was affected by drought stress in a similar manner (assuming nitrogen and protein concentration to be correlated), whereas for zinc opposite results were observed. This discrepancy might be caused by the different levels and the timing of drought stress applied. While in our study the drought stress treatment was started before the maize plants reached their full height, in the study of Oktem (2008), drought stress was applied in a much earlier developmental stage of the maize after an initial irrigation. The occurrence of drought in different developmental stages between the two studies might be the reason for the difference in its effect on elemental composition. Ge et al. (2010) examined elemental composition in kernels of maize grown under severe drought stress and found increased concentrations of calcium, magnesium and zinc, while concentrations of phosphorous and potassium were decreased. Drought stress impacts found in our study largely confirm the findings of Ge et al. (2010) with the exception of phosphorous which was not affected. In our study, interactions between the $\mathrm{CO}_{2}$ and the water treatment were observed for the concentrations of nitrogen, potassium, magnesium and zinc. The drought stress impacts were less pronounced under elevated $\mathrm{CO}_{2}$ for the concentrations of nitrogen, magnesium and zinc. As an exception, there were more prominent drought-induced impacts on the potassium concentration under elevated than under ambient $\mathrm{CO}_{2}$.

\subsection{Quality characteristics of maize aboveground biomass}

In the current study, the concentrations of lignin, acid and neutral detergent fiber (Table 2) were in the same order of magnitude as found in other studies on maize (Wiersma et al. 1993; Cox et al. 1994; Tolera and Sundstol 1999). Neutral detergent fiber and starch concentration of maize aboveground biomass in the well-watered treatment were affected by the factor year and thus by the differences between both growing seasons (Table 1). In 2008, drought stress increased the concentrations of crude fiber, acid and neutral detergent fiber in a comparable magnitude by $16 \%$ and $9 \%, 19 \%$ and $9 \%$, as well as $16 \%$ and $8 \%$ under ambient and elevated $\mathrm{CO}_{2}$, respectively (Fig. 3). In contrast, Kruse et al. (2008) detected changes in soil water availability to have only minor impact on maize cell wall fractions in a modeling approach. Wiersma et al. (1993) reported drought-induced decreases in 


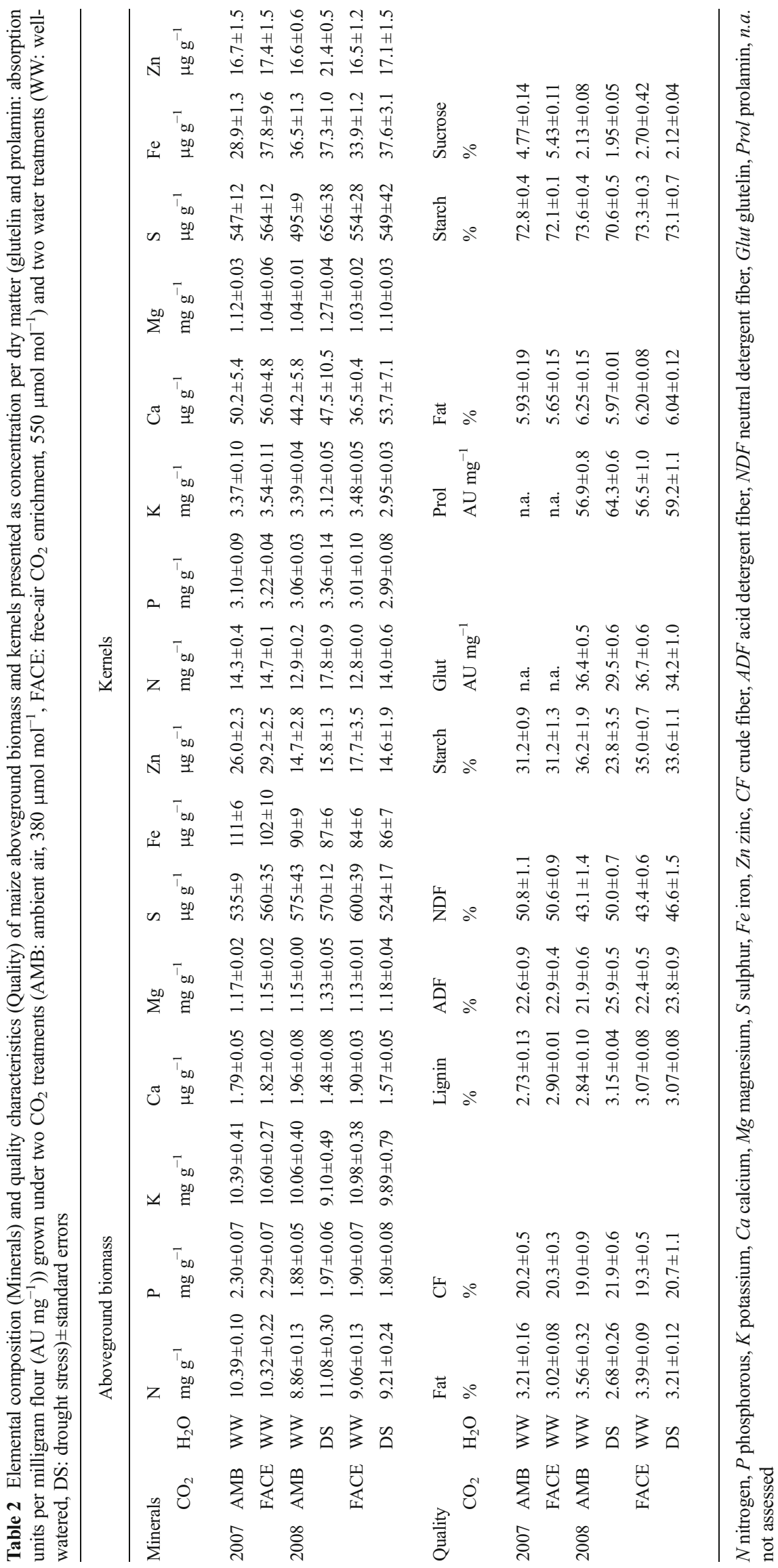


Fig. 2 Change ratio of mineral concentrations of maize aboveground biomass and kernels grown under drought stress (DS), elevated $\mathrm{CO}_{2}$ concentration (FACE: free-air $\mathrm{CO}_{2}$ enrichment to $550 \mu \mathrm{mol} \mathrm{mol}^{-1}$ ) and the combination of both treatments (DS+FACE) in the 2008 growing season. Results are given relative to the respective data of the AMB WW treatment used as reference. Only significant results are shown $(* * * p<0.001 ; * * 0.001 \leq p<0.01$; $* 0.01 \leq p<0.05)$. Abbreviations: see Tables 1 and 2

\section{Change ratio in aboveground biomass}
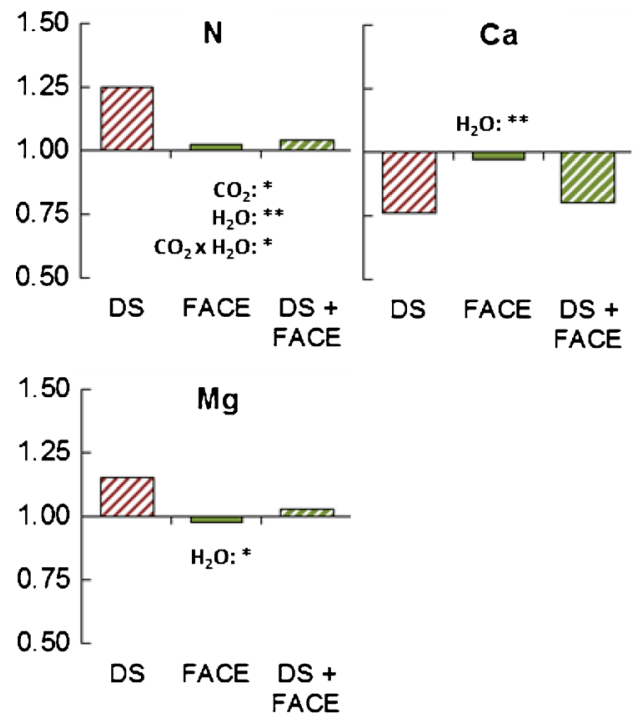

\section{Change ratio in} kernels
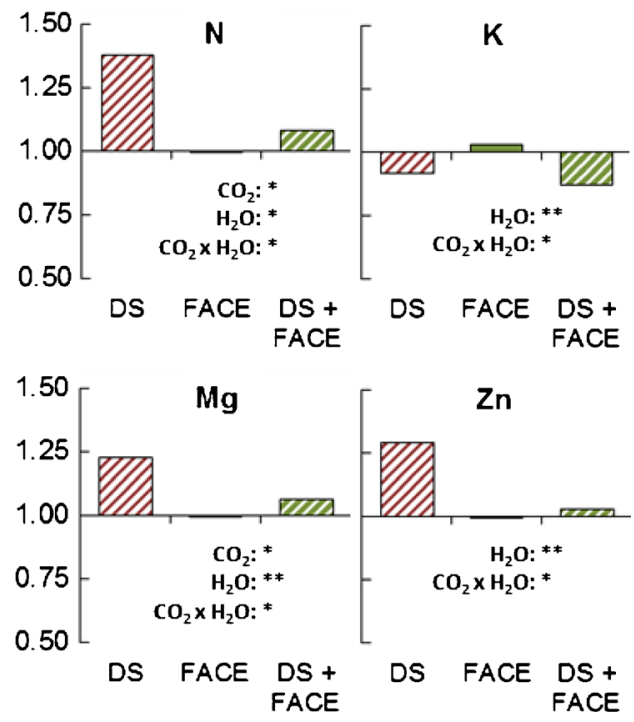

maize crude fiber, acid and neutral detergent fiber, which is not in agreement with our results. Again, the reason for this discrepancy might be the different levels and the timing of drought stress applied compared with our study. Wiersma et al. (1993) compared growing seasons with different levels of ambient precipitation, which resulted in a dry growing season in one year. In our study, drought stress was experimentally imposed on the plants starting in the middle of the growing season. The different developmental stages at which drought occurred could be the reason for the different results between the studies. According to Kruse et al. (2008), drought stress induced increases in fiber concentrations as also found in our study will reduce the usability of maize for silage and bioenergy production, because an altered cell wall composition may limit digestibility, feed intake of ruminants and reduce methane output in biogas plants. Lohölter et al. (2012) and Wroblewitz et al. (2013) examined the in vivo digestibility of maize from the present experiment but came to differing results. A potential reason for these differing results might be that the plants used in these analyses were harvested about 3 weeks later than the ones analysed in the present study. According to Lindroth and Dearing (2005), elevated $\mathrm{CO}_{2}$ increases concentrations of carbon-based plant compounds. Our results on the $\mathrm{C}_{4}$ plant maize do not agree with
Fig. 3 Change ratio of quality characteristic concentrations of maize aboveground biomass and kernels grown under drought stress (DS), elevated $\mathrm{CO}_{2}$ concentration (FACE: free-air $\mathrm{CO}_{2}$ enrichment to $550 \mu \mathrm{mol} \mathrm{mol}^{-1}$ ) and the combination of both treatments (DS+FACE) in the 2008 growing season. Results are given relative to the respective data of the AMB WW treatment used as reference. Only significant results are shown $(* * * p<0.001 ; * * 0.001 \leq p<0.01$; $* 0.01 \leq p<0.05$ ). Abbreviations: see Tables 1 and 2

\section{Change ratio in aboveground biomass}
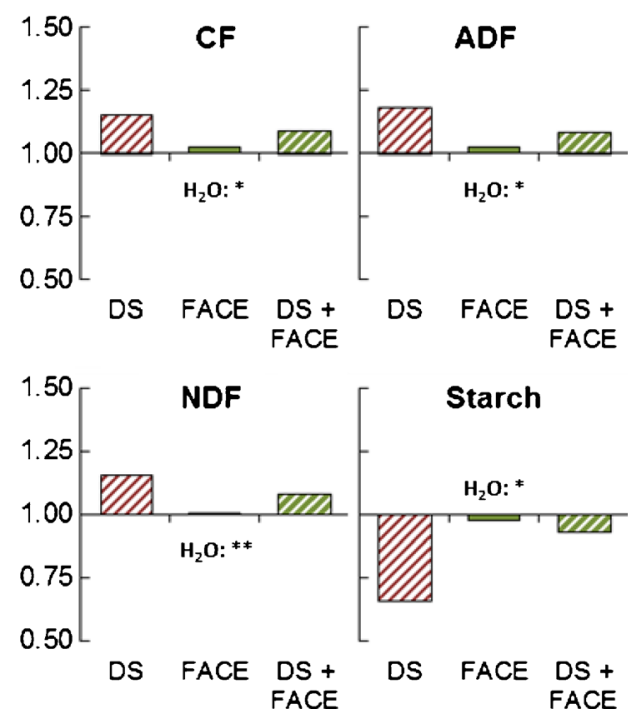

\section{Change ratio in kernels}
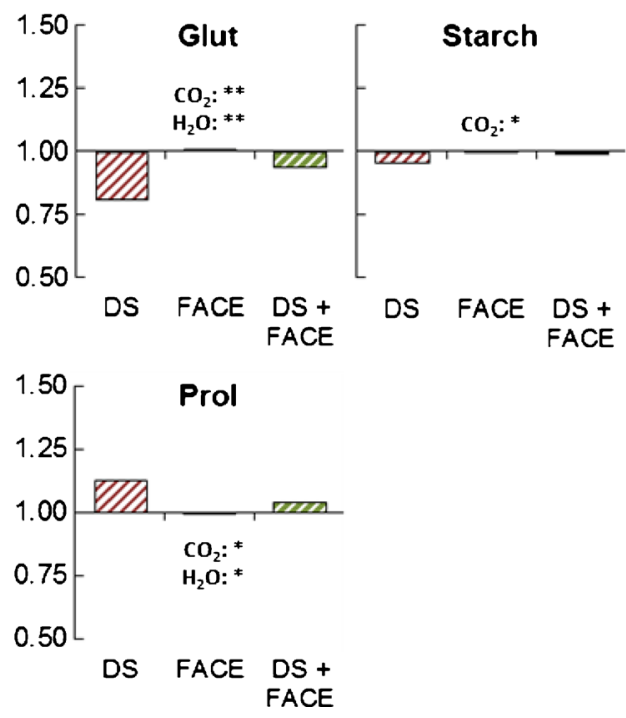
this finding because no respective changes were found in the carbon-based compounds investigated (crude fiber, lignin, acid and neutral detergent fiber, starch and sucrose). However, drought stress-induced increases were observed in crude fiber and acid and neutral detergent fiber. Starch concentrations were decreased due to drought stress by $34 \%$ and $7 \%$ in ambient and elevated $\mathrm{CO}_{2}$, respectively. In a growth chamber experiment with maize and sorghum, Kakani et al. (2011) found drought stress to decrease starch concentration, which is confirmed by our results.

\subsection{Quality characteristics of maize kernels}

Kernels of common maize varieties consist of about $70 \%$ starch, $10 \%$ protein and $4 \%$ fat (Nuss and Tanumihardjo 2010) which is consistent with our findings (Table 2). In the data of the well-watered treatment, concentrations of fat, starch and sucrose were affected by the growing season (Table 1). In 2008 (Table 2, Fig. 3), $\mathrm{CO}_{2}$ enrichment increased the concentration of the protein fraction glutelin by $1 \%$, while drought stress resulted in decreases of $19 \%$ in ambient and $6 \%$ in elevated $\mathrm{CO}_{2}$. The concentration of the protein fraction prolamin was reduced under ample water supply and elevated $\mathrm{CO}_{2}$ by $1 \%$, while under drought stress increases of $13 \%$ and $4 \%$ in ambient and elevated $\mathrm{CO}_{2}$ were observed, respectively. These results are in contrast to those for the concentrations of protein fractions of winter wheat which were reduced by $\mathrm{CO}_{2}$ enrichment (Wieser et al. 2008; Högy et al. 2009). Wang and Frei (2011) identified common stress responses of environmental impacts, including drought stress on maize quality characteristics such as increased protein concentration and a loss in starch and fat concentration. The results of our study confirm these findings for the protein fraction prolamin. In $\mathrm{C}_{3}$ crops, elevated $\mathrm{CO}_{2}$ is known to decrease grain nitrogen and protein concentrations (Weigel and Manderscheid 2005; Taub et al. 2008; Högy and Fangmeier 2008; Erbs et al. 2010; McGrath and Lobell 2013). According to our results, a reduction of kernel quality under elevated $\mathrm{CO}_{2}$ due to lower nitrogen and protein concentrations in maize seems not to be relevant. In the present study, the concentration of starch was decreased by $1 \%$ under elevated $\mathrm{CO}_{2}$, which is the only trait that shows a $\mathrm{CO}_{2}$ effect that is not accompanied with a drought stress effect.

The results obtained in the present study only partly confirm our hypotheses. Elevated $\mathrm{CO}_{2}$ did not generally reduce mineral concentrations of maize aboveground biomass and kernels under ample water supply. Hence hypothesis (1) was not confirmed. In contrast, hypothesis (2) was found to be confirmed for nearly all traits because the dimensions of the drought stress effects were smaller under elevated $\mathrm{CO}_{2}$ (exception: kernel potassium concentration). The $\mathrm{C}_{4}$ plant maize was not affected by elevated $\mathrm{CO}_{2}$ alone and thus reacted different than $\mathrm{C}_{3}$ plants. Our results clearly demonstrate the impacts of drought stress on maize elemental composition and quality characteristics. However, the increase in atmospheric $\mathrm{CO}_{2}$ concentration will mostly mitigate the effects of drought. To our knowledge, this is the first report on the effects of elevated $\mathrm{CO}_{2}$ and controlled drought stress on elemental composition and quality traits in maize grown under real field conditions.

\section{Conclusions}

The current results obtained under realistic agronomic conditions clearly show that drought stress will alter the elemental composition and quality characteristics of maize aboveground biomass and kernels. No significant influence of elevated $\mathrm{CO}_{2}$ was observed under adequate water supply in both growing seasons. Effects of elevated $\mathrm{CO}_{2}$ were only significant when drought stress effects were significant, too. Food and feed quality of aboveground biomass was modified by drought stress due to increases in concentrations of nitrogen, magnesium, crude fiber and acid and neutral detergent fiber, as well as by lower concentrations of calcium and starch. In maize kernels, drought stress modified the food and feed quality by increasing the concentrations of nitrogen, magnesium, zinc and prolamin and by reducing concentrations of potassium and glutelin. In all of these traits, the impacts of drought were considerably smaller in the combined treatment including also $\mathrm{CO}_{2}$ enrichment. Thus, elevated $\mathrm{CO}_{2}$ partially mitigated the drought stress impacts on maize. The results of the present study point out the necessity that, in projections on maize elemental composition and quality traits, the interactive effects of drought stress and elevated $\mathrm{CO}_{2}$ concentration, two important elements of future climatic conditions, have to be included.

Acknowledgements This research was part of the research project LandCaRe 2020 funded by the German Federal Ministry of Education and Research (BMBF). The FACE apparatus was engineered by Brookhaven National Laboratory and we are grateful to Dr. George Hendrey, Keith Lewin, and Dr. John Nagy for their support. We acknowledge the technical assistance and the work of the people from the ThünenInstitutes of Biodiversity and Climate-Smart Agriculture and from the Institute of Animal Nutrition of the Friedrich Loeffler-Institut contributing to the Braunschweig FACE experiment. The experimental station of the Friedrich Loeffler-Institut, Braunschweig, is thanked for carrying out the agricultural measures at the experimental area.

\section{References}

Ainsworth EA, Beier C, Calfapietra C, Ceulemans R, Durand-Tardif M, Farquhar GD, Godbold DL, Hendrey GR, Hickler T, Kaduk J, Karnosky DF, Kimball BA, Körner C, Koornneef M, Lafarge T, Leakey ADB, Lewin KF, Long SP, Manderscheid R, McNeil DL, Mies TA, Miglietta F, Morgan JA, Nagy J, Norby RJ, Norton RM, 
Percy KE, Rogers A, Soussana J-F, Stitt M, Weigel H-J, White JW (2008) Next generation of elevated $\left[\mathrm{CO}_{2}\right]$ experiments with crops: a critical investment for feeding the future world. Plant Cell Environ 31:1317-1324. doi:10.1111/j.1365-3040.2008.01841.x

Cox WJ, Cherney JH, Cherney DJR, Pardee WD (1994) Forage quality and harvest index of corn hybrids under different growing conditions. Agron J 86:277-282. doi:10.2134/agronj1994. 00021962008600020013x

Crasta OR, Cox WJ, Cherney JH (1997) Factors affecting maize forage quality development in the northeastern USA. Agron J 89:251-256. doi:10.2134/agronj1997.00021962008900020016x

Erbs M, Manderscheid R, Jansen G, Seddig S, Pacholski A, Weigel H-J (2010) Effects of free-air $\mathrm{CO}_{2}$ enrichment and nitrogen supply on grain quality parameters and elemental composition of wheat and barley grown in a crop rotation. Agric Ecosyst Environ 136:59-68. doi:10.1016/j.agee.2009.11.009

Erbs M, Manderscheid R, Weigel H-J (2012) A combined rain shelter and free-air $\mathrm{CO}_{2}$ enrichment system to study climate change impacts on plants in the field. Methods Ecol Evol 3:81-88. doi:10.1111/j.2041210X.2011.00143.x

FAO (2011) FAOSTAT. http://faostat.fao.org/site/339/default.aspx. Accessed 31 Jan 2013

Ge T, Sui F, Nie SA, Sun N, Xiao HA, Tong C (2010) Differential responses of yield and selected nutritional compositions to drought stress in summer maize grains. J Plant Nutr 33:1811-1818. doi:10. $1080 / 01904167.2010 .503829$

Ghannoum O (2009) $\mathrm{C}_{4}$ photosynthesis and water stress. Ann Bot 103: 635-644. doi:10.1093/aob/mcn093

Ghannoum O, von Caemmerer S, Ziska LH, Conroy JP (2000) The growth response of $\mathrm{C}_{4}$ plants to rising atmospheric $\mathrm{CO}_{2}$ partial pressure: a reassessment. Plant Cell Environ 23:931-942. doi:10. 1046/j.1365-3040.2000.00609.x

Ghannoum O, Searson MJ, Conroy JP (2006) Nutrient and water demands of plants under global climate change. In: Newton PCD, Carran RA, Edwards GR, Niklaus PA (eds) Agroecosystems in a changing climate. CRC Taylor \& Francis, Boca Raton, pp 53-83. doi:10.1201/9781420003826.ch3

Högy P, Fangmeier A (2008) Effects of elevated atmospheric $\mathrm{CO}_{2}$ on grain quality of wheat. J Cereal Sci 48:580-591. doi:10.1016/j.jcs. 2008.01.006

Högy P, Wieser H, Koehler P, Schwadorf K, Breuer J, Franzaring J, Muntifering R, Fangmeier A (2009) Effects of elevated $\mathrm{CO}_{2}$ on grain yield and quality of wheat: results from a 3-year free-air $\mathrm{CO}_{2}$ enrichment experiment. Plant Biol 11:60-69. doi:10.1111/j.14388677.2009.00230.x

Johnson L, Harrison JH, Hunt C, Shinners K, Doggett CG, Sapienza D (1999) Nutritive value of corn silage as affected by maturity and mechanical processing: a contemporary review. J Dairy Sci 82: 2813-2825. doi:10.3168/jds.S0022-0302(99)75540-2

Kakani VG, Vu JCV, Allen LH, Boote KJ (2011) Leaf photosynthesis and carbohydrates of $\mathrm{CO}_{2}$-enriched maize and grain sorghum exposed to a short period of soil water deficit during vegetative development. J Plant Physiol 168:2169-2176. doi: 10.1016/j.jplph.2011.07.003

Kimball BA, Kobayashi K, Bindi M (2002) Responses of agricultural crops to free-air $\mathrm{CO}_{2}$ enrichment. Adv Agron 77:293-368. doi:10. 1016/S0065-2113(02)77017-X

Kruse S, Herrmann A, Kornher A, Taube F (2008) Evaluation of genotype and environmental variation in fibre content of silage maize using a model-assisted approach. Eur J Agron 28:210-223. doi:10. 1016/j.eja.2007.07.007

Leakey ADB, Uribelarrea M, Ainsworth EA, Naidu SL, Rogers A, Ort DR, Long SP (2006) Photosynthesis, productivity, and yield of maize are not affected by open-air elevation of $\mathrm{CO}_{2}$ concentration in the absence of drought. Plant Physiol 140:779-790. doi:10.1104/ pp. 105.073957
Lindroth RL, Dearing MD (2005) Herbivory in a world of elevated $\mathrm{CO}_{2}$. In: Ehleringer JR, Cerling TE, Dearing MD (eds) A history of atmospheric $\mathrm{CO}_{2}$ and its effects on plants, animals, and ecosystems. Springer, New York, pp 468-486. doi:10.1007/ 0-387-27048-5 21

Lohölter M, Meyer U, Manderscheid R, Weigel H-J, Erbs M, Flachowsky G, Daenicke S (2012) Effects of free air carbon dioxide enrichment and drought stress on the feed value of maize silage fed to sheep at different thermal regimes. Arch Anim Nutr 66:335-346. doi:10. 1080/1745039x.2012.697352

Loladze I (2002) Rising atmospheric $\mathrm{CO}_{2}$ and human nutrition: toward globally imbalanced plant stoichiometry? Trends Ecol Evol 17:457461. doi:10.1016/S0169-5347(02)02587-9

Long SP, Ainsworth EA, Leakey ADB, Nösberger J, Ort DR (2006) Food for thought: lower-than-expected crop yield stimulations with rising $\mathrm{CO}_{2}$ concentrations. Science 312:1918-1921. doi:10.1126/science. 1114722

Manderscheid R, Erbs M, Weigel H-J (2014) Interactive effects of free-air $\mathrm{CO}_{2}$ enrichment and drought stress on maize growth. Eur J Agron 52:11-21. doi:10.1016/j.eja.2011.12.007

Markelz RJC, Strellner RS, Leakey ADB (2011) Impairment of C-4 photosynthesis by drought is exacerbated by limiting nitrogen and ameliorated by elevated $\mathrm{CO}_{2}$ in maize. J Exp Bot 62:3235-3246. doi:10.1093/jxb/err056

McGrath JM, Lobell DB (2013) Reduction of transpiration and altered nutrient allocation contribute to nutrient decline of crops grown in elevated $\mathrm{CO}_{2}$ concentrations. Plant Cell Environ 36:697-705. doi: 10.1111/pce. 12007

Meehl GA, Stocker TF, Collins WD, Friedlingstein P, Gaye AT, Gregory JM, Kitoh A, Knutti R, Murphy JM, Noda A, Raper SCB, Watterson IG, Weaver AJ, Zhao Z-C (2007) Global climate projections. In: Solomon S, Qin D, Manning M, Chen Z, Marquis M, Averyt KB, Tignor M, Miller HL (eds) Climate change 2007: the physical science basis. Contribution of the working group I to the fourth assessment report of the intergovernmental panel on climate change. Cambridge University Press, Cambridge, pp 747-845

Mota Oliveira EM, Ruiz HA, Alvarez VVH, Ferreira PA, Costa FO, Carreiro Almeida IC (2010) Nutrient supply by mass flow and diffusion to maize plants in response to soil aggregate size and water potential. Rev Bras Cienc Solo 34:317-327. doi:10.1590/S010006832010000200005

Nuss ET, Tanumihardjo SA (2010) Maize: a paramount staple crop in the context of global nutrition. Compr Rev Food Sci F 9:417-436. doi: 10.1111/j.1541-4337.2010.00117.x

Oktem A (2008) Effect of water shortage on yield, and protein and mineral compositions of drip-irrigated sweet corn in sustainable agricultural systems. Agric Water Manag 95:1003-1010. doi:10. 1016/j.agwat.2008.03.006

Pingali PL (2009) CIMMYT 1999-2000 World maize facts and trends. Meeting world maize needs: technological opportunities and priorities for the public sector. CIMMYT, Mexico. ISSN: $0257-8743$

Rastija M, Kovacevic V, Rastija D, Simic D (2010) Manganese and zinc concentrations in maize genotypes grown on soils differing in acidity. Acta Agron Hung 58:385-393. doi:10.1556/AAgr.58.2010.4.7

Taub DR, Wang X (2008) Why are nitrogen concentrations in plant tissue lower under elevated $\mathrm{CO}_{2}$ ? A critical examination of hypotheses. J Integr Plant Biol 50:1365-1374. doi:10.1111/j.1744-7909.2008. 00754.x

Taub DR, Miller B, Allen H (2008) Effects of elevated $\mathrm{CO}_{2}$ on protein concentration of food crops: a meta-analysis. Glob Chang Biol 14: 565-575. doi:10.1111/j.1365-2486.2007.01511.x

Tolera A, Sundstol F (1999) Morphological fractions of maize stover harvested at different stages of grain maturity and nutritive value of different fractions of the stover. Anim Feed Sci Technol 81:1-16. doi:10.1016/s0377-8401(99)00072-3 
Van Soest PJ, Robertson JB, Lewis BA (1991) Methods for dietary fiber, neutral detergent fiber, and nonstarch polysaccharides in relation to animal nutrition. J Dairy Sci 74:3583-3597. doi:10.3168/jds.S00220302(91)78551-2

VDLUFA Verband Deutscher Landwirtschaftlicher Untersuchungs- und Forschungsanstalten (2006) Die chemische Untersuchung von Futtermitteln. Handbuch der Landwirtschaftlichen Versuchs- und Untersuchungsmethodik (VDLUFA-Methodenbuch), Band III. Darmstadt, Germany. VDLUFA-Verlag. ISSN: 3-922712-94-0

Wang Y, Frei M (2011) Stressed food - the impact of abiotic environmental stresses on crop quality. Agric Ecosyst Environ 141:271286. doi:10.1016/j.agee.2011.03.017

Weigel H-J, Manderscheid R (2005) $\mathrm{CO}_{2}$ enrichment effects on forage and grain nitrogen content of pasture and cereal plants. J Crop Improv 13:73-89. doi:10.1300/J411v13n01_05
Wiersma DW, Carter PR, Albrecht KA, Coors JG (1993) Kernel milkline stage and corn forage yield, quality, and dry matter content. J Prod Agric 6:94-99. doi:10.2134/jpa1993.0094

Wieser H, Antes S, Seilmeier W (1998) Quantitative determination of gluten protein types in wheat flour by reversed-phase highperformance liquid chromatography. Cereal Chem 75:644-650. doi:10.1094/CCHEM.1998.75.5.644

Wieser H, Manderscheid R, Erbs M, Weigel H-J (2008) Effects of elevated atmospheric $\mathrm{CO}_{2}$ concentrations on the quantitative protein composition of wheat grains. J Agric Food Chem 56:6531-6535. doi:10.1021/jf8008603

Wroblewitz S, Hüther L, Manderscheid R, Lebzien P, Danicke S (2013) The effect of free air carbon dioxide enrichment (FACE) during maize cultivation on the in sacco degradability of the grains. Proc Soc Nutr Physiol 22:118 